\title{
CELLULÁRIS ANYAGOK MODELLEZÉSE DIGITÁLIS KÉPEK ALAPJÁN
}

\section{MODELLING OF CELLULAR MATERIALS BASED ON DIGITAL IMAGES}

\author{
Varga Tamás Antal ${ }^{1}$, Kapusi Tibor ${ }^{2}$, Mankovits Tamás ${ }^{3}$ \\ I'Debreceni Egyetem, Müszaki Kar, Gépészmérnöki Tanszék, 4028 Magyarország \\ Debrecen, Ótemetö utca 2-4.; +36-52-415-155/77704, varga.tamas@eng.unideb.hu \\ ${ }^{2}$ Debreceni Egyetem, Informatikai Kar, Komputergrafika és Képfeldolgozás \\ Tanszék, 4028 Magyarország Debrecen, Kassai út 26.; +36-20-406-12-97, \\ haegemonia2@gmail.com \\ ${ }^{3}$ Debreceni Egyetem, Müszaki Kar, Gépészmérnöki Tanszék, 4028 Magyarország \\ Debrecen, Ótemetö utca 2-4.; Tel.: +36-52-415-155/77775, \\ tamas.mankovits@eng.unideb.hu
}

\begin{abstract}
The geometrical modelling of cellular materials is still one of the greatest challenges of engineers. In this paper the modelling of closed-cell aluminium foam with some methods. These include geometric reconstruction, idealized models. In addition, the software will be presented a theoretical operation, which can be determined by the internal structure, and uses this data to a model building method of cellular materials.
\end{abstract}

Keywords: modelling, structure analysis, recontruction, cellular materials, foamstructure

\section{Összefoglalás}

A celluláris szerkezetü anyagok geometriai modellezése egy jelenleg is kutatott témakör. Jelen cikkben zártcellás aluminiumhabok belső szerkezetének modellezését mutatjuk be több féle módszer szerint. Ezek között szerepel a geometriai rekonstrukció, idealizált modellek. Ezen kivül bemutatásra kerül egy olyan szoftver elméleti müködése, amellyel meghatározható lehet a celluláris anyagok belsö szerkezete, illetve ezen adatok alapján egy modellt felépitö eljárás.

Kulcsszavak: modellezés, struktúraelemzés, rekonstrukció, celluláris anyagok, habstruktúra

\section{Bevezetés}

A mai korszerü anyagtudományban, számos olyan anyag előállításával foglalkoznak, amelynek a belseje celluláris kialakítású. Ezek a struktúrákat azért érdemes kialakítani, mivel a belső szerkezete úgynevezett „szivacsos” kialakításúak lesznek, ennek köszönhetően a relatív tömegük jelentősen lecsökken, míg a mechanikai és fizikai tulajdonságaik kiválóak maradnak. Ilyen celluláris kialakítású anyagok legelterjedtebb formája a fémhabok. A következőekben a fémhabokat fogjuk elemezni, amelyek készülhetnek akár alumíniumból, vagy akár titánhabból is, amely biokompatibilis az emberi szervezettel. 
A fémhab viszonylag régóta ismert anyag, de ipari és orvosi alkalmazása csak az elmúlt pár évben kezdett széles körben elterjedni. Ez annak köszönhetö, hogy mára már megbízható eljárások léteznek a gyártási technológiára, amely technológia eredményeképpen szabályozható az előállításra kerülő fémhab belső szerkezete. Köztudott, hogy a fémhaboknak kicsi a sürüsége, de ennek ellenére kiváló mechanikai és fizikai tulajdonságokkal rendelkeznek [1-4]. Emellett számos olyan pozitív tulajdonságuk van, amelynek eredményeként nemcsak rezgés-, vagy ütközéscsillapításra alkalmasak, hanem teherviselő elemként (jármüalkatrész, implantátum) is kiválóan helytállnak. Számos tanulmány számolt be alkalmazási lehetőségekről és jól látható, hogy a mérnöki és orvosi alkalmazásuk rohamosan terjed, amely a jövő egyik meghatározó anyagtípusává teszi a fémhabot. Teherviselő fémhabok esetén különösen elötérbe kerül a terméktervezési folyamat problematikája, amelynek központi kérdése a geometriai modellezés és a numerikus szimuláció. Teherviselő anyagként azt várjuk a fémhabtól, hogy az alkalmazás során rugalmasan viselkedjen, így megfelelő biztonsággal kell ismernünk, vagy képeseknek kell lennünk megbecsülni az anyagunk válaszát az adott terhelésre. Ehhez a valósághoz közeli modellt szükséges kifejleszteni, amelyre kétféle stratégiát választhatunk: idealizált modell kifejlesztése [5-8], valós geometria rekonstruálása [9-13]. Annak érdekében, hogy egy idealizált geometriai modellt tudjunk elöállítani a fémhabról kellő információval kell rendelkeznünk annak a belső szerkezetéről, amely a fizikai és mechanikai tulajdonságait közvetlenül befolyásolják. Tekintve, hogy a fémhabok belső szerkezete meglehetősen bonyolult, így felületelemzéssel csak hiányos, sok esetben pedig félrevezető információhoz juthatunk. Leghatékonyabban CT felvételek készítésével lehet feltérképezni a fémhabok belső struktúráját [9-13], amely jelenleg a legkorszerübb eljárás.

\section{Modellezési lehetőségek}

A fémhab geometriai modellezését alapvetően kétféle stratégiával lehet megvalósítani. Az egyik az, amikor különböző vizsgálati módszerekkel (mikroszkópos vizsgálat, CT vizsgálat) meghatározott adatokból felépítünk egy olyan idealizált modellt, amely hasonlóan viselkedik terhelés hatására, mint az eredeti. A másik lehetőség az, hogy a legyártott fémhabról készült CT felvételek segítségével építjük fel a valós geometriai modellt. Mindkét eljárásnak van előnye és hátránya is. Az idealizált modell előnye, hogy néhány előre meghatározott adatból képesek vagyunk felépíteni egy modellt, de a nagy hátránya az, hogy csak megközelítőleg tudjuk szimulálni a fémhab reakcióját, hiszen ez a 3D-s modell nem teljesen egyezik meg a legyártott próbatesttel. A CT felvételnek nagy előnye, hogy ugyanazt a 3D-s geometriát tudjuk vizsgálni, mint a vizsgált fémhab. Hátránya, hogy a gyártástechnológiából fakadó nehéz reprodukálhatóság miatt csak a konkrét fémhab szerkezetre tudunk információt szolgáltatni. A CT felvételes eljárás nagyon költséges, illetve nehezen kivitelezhetö, mert nem áll könnyen rendelkezésre ipari CT berendezés, illetve ezeknek a modelleknek óriási számítási igényük van. A fémhabok geometriai modellezése és azok végeselemes analízise komoly mérnöki feladat, amelynek eredményeképpen a legyártásra kerülő fémhab alkatrész tervezhető és optimalizálható lesz. $\mathrm{Az}$ utóbbi években számos kutató foglalkozott a fémhabok modellezésével és végeselem szimulációjával, több-kevesebb sikerrel. 


\subsection{Idealizált modellek}

A celluláris anyagokat lehetőségünk van idealizált modellenként felépíteni. Ahoz, hogy így tudjunk modellezni anyagokat, szükségünk van pár elengedhetetlen információra az anyagunkkal kapcsolatban. Ilyenek például a modellt felépítő cellák átméröi, azoknak elhelyezkedése a térben. Ezeket lehetőségünk van meghatározni, a fémhab oldalairól készült felvételeken lemért cellák átmérőivel. Ez eljárás alapjául szolgálhat egy a próbatest oldaláról elkészített digitális kép (macro felvétel), vagy akár egy mikroszkóp által elkészített felvétel is (1.ábra).

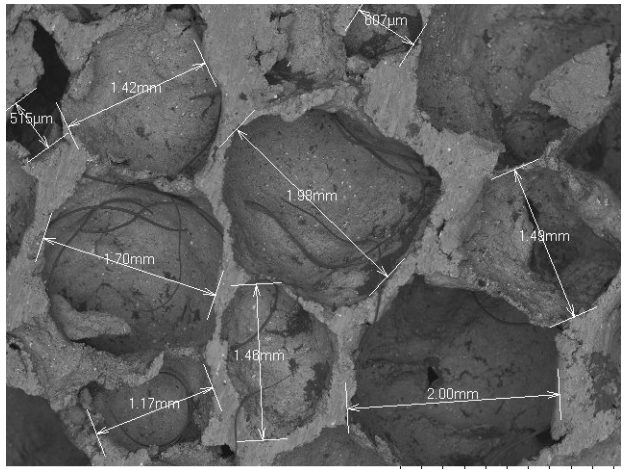

1. ábra. Fémhabról készitett mikroszkópos felvétel a cellaátmérökkel meghatározva

Egy másik eljárás lehet a struktúra elemzésére egy CT berendezés által feltérképezett geometria, amelyet később egy célszoftverrel megvizsgálva meg tudjuk határozni a modell felépítéséhez szükséges adatokat. Ezen adatokból képesek vagyunk felépíteni a modellünket, amelyeket több fajta eljárással tehetünk meg. A 3D-s idealizált modelljének több fajtája is van, ezek közül a leggyakrabban alkalmazott modell a Gibson-Ashby modell, ahol az egységcella kocka. Léteznek továbbá beágyazásos és statisztikus modellek is. Az idealizált modellek általában nem túlságosan pontosak, de könnyen modellezhetőek és szimulálhatóak.

\subsection{Rekonstrukciós eljárás}

A rekonstrukciós eljárás alapjául is szintén digitális képek szolgálnak, amelyek szintén egy $\mathrm{CT}$ berendezés segítségével készültek el. A CT felvételek a 3D-s geometriát bizonyos távolságokban elvágja, amelyekről egy 2D-s felvételt készít. A rekonstrukciós eljárásunk során ezeket a 2D-s felvételeket kell összeállítanunk egy célszoftver segítségével 3D-s modellé. Ezek a modellek rendszerint, csak vizuális elemzésre szolgálnak, tehát különbözö szimulációs szoftverekkel ezeket nem vagyunk képesek elemezni Ezért elengedhetetlen, hogy ezen a geometriát tovább módosítsuk úgy, hogy ezek alapján egy CAD geometriát kapjunk, amelyekből akár végeselemes háló is készíthető. Sikeresen létre tudtunk hozni egy olyan eljárást, amellyel egy CT felvételekből álló fájlokból egy végeselem hálót tudjunk létrehozni úgy, hogy a rekonstrukciós eljárás során csökkentsük az adott fájl méreteit, úgy hogy azoknak a térfogata, illetve fizikai tulajdonsági ne változzanak. Ezt az eljárást a későbbiekben kívánjuk bemutatni.

\section{Következtetések}

Amint látható a celluláris anyagok igazán jelentős napjainkban, mivel a relatív tömegük kicsi, míg a fizikai tulajdonságaik kiválóak. Ezeknek az anyagoknak a modellezése különböző módon lehetséges. Ilyenek lehetnek az idealizált modellek, amelyek pár meghatározó adatból képesek vagyunk felépíteni. Sajnos ezek a modellek közel sem olyan pontosak, mint a valódi geometria, de ezeket könnyen lehet modellezni, és közelítő értékeket képesek vagyunk meghatározni. Ettől már sokkal jobb a CT felvételek alapján rekonstruált geometria, mivel ez szinte teljes egészében megegyezik a valós geometriával. Ennek az eljárásnak az egyetlen legnagyobb hátránya, hogy ez az eljárás eszköz igényes, illetve 
komoly rekonstrukciós eljárásnak köszönhetően eléggé számítógép igényes, amelyet egy átlagos asztali számítógépen nem lehet elvégezni.

\section{Köszönetnyilvánítás}

\section{AZ EMBERI ERÖFORRÁSOK} MINISZTÉRIUMA ÚJ NEMZETI KIVÁLÓSÁG PROGRAMJÁNAK TÁMOGATÁSÁVAL KÉSZÜLT

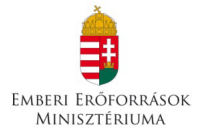

\section{Szakirodalmi hivatkozások}

[1] Ashby, M.F., Evan, A.G., Fleck, N.A., Gibson, L.J., Hutchinson, J.W., Wadley, H.N.G: Metal Foams: A Design Guide. Butterworth-Heinemann, 2000.

[2] Mankovits, T., Budai, I., Balogh G., Gábora, A., Kozma, I., Varga, T., Manó, S., Kocsis, I., Structural Analysis and its Statistical Evaluation of a Closed-Cell Metal Foam. International Review Applied Science Engineering, 2014, 135-143.

[3] Orbulov, I.N., Compressive properties of aluminium matrix syntactic foams. Materials Science and Engineering A, 2012, 52-56.

[4] Orbulov, I.N., Májlinger, K., Description of the compressive response of metal matrix syntactic foams. Materials and Design, 2013, $1-9$.

[5] Kou, D.P., Li, J.R., Yu, J.L., Cheng, H.F., Mechanical behavior of open-cell metallic foams with dual-size cellular structure. Scripta Materialia, 2008, 483-486.

[6] Jang, W.Y., Kyriakides, S., Kraynik, A.M., On the compressive strength of open-cell metal foams with Kelvin and random cell structures. International Journal of Solids and Structures, 2010, 2872-2883.

[7] Lu, Z.X., Liu, Q., Huang, J.X., Analysis of defects on the compressive behaviors of open-cell metal foams through models using the FEM. Materials Science and Engineering A, 2011, 285-296.

[8] An, Y., Wen, C., Hodgson, P.D., Yang, C., Investigation of cell shape effect on the mechanical behaviour of open-cell metal foams. Computational Materials Science, 2012, 1-9.

[9] Maire, E., Fazekas, A., Salvo, L., Dendievel, R., Youssef, S., Cloetens, P., Letang, J.M., $X$ ray tomography applied to the characterization of cellular materials. Related finite element modeling problems. Composites Science and Technology, 2003, 2431-2443.

[10] Jirousek, O., Doktor, T., Kytyr, D., Zlámal, P., Fíla, T., Koudelka, P., Jandejsek, I., Vavrík, D., X-ray and finite element analysis of deformation response of closed-cell metal foam subjected to compressive loading. Journal of Instrumentation, 2013.

[11] Youssef, S., Maire, E., Gaertner, R., Finite element modelling of the actual structure of cellular materials determined by $X$-ray tomography. Acta Materialia, 2005, 719-730.

[12] Veyhl, C., Belova, I.V., Murch, G.E., Fiedler, T., Finite element analysis of the mechanical properties of cellular aluminium based on micro-computed tomography. Materials Science and Engineering A, 2011, 4550-4555.

[13] Jeon, I., Asahina, T., Kang, K.J., Im, S., Lu, T.J., Finite element simulation of the plastic collapse of closed-cell aluminum foams with X-ray computed tomography. Mechanics of Materials, 2010, 227-236. 